Such an arrangement can produce three types of image: (a) when the polarizers are crossed, pure fluorescence microscopy is realized; $(b)$ when they are parallel a practically pure phase image is obtained because the fluorescent image becomes too weak to be seen; (c) according to the orientation of the polarizer, any intermediate images can be obtained. Therefore, one can observe simultaneously fluorescence and phase images.

If the polarizing material is placed on the ocular, according to its orientation, the three types of images can be observed. If the specimens are birefringent, a polarizing image is also obtained. However, this arrangement may weaken the intensity of the fluorescence. It should be possible to insert a polarizing ring in the objective to overcome the difficulty above.

This arrangement is not only useful for algal work, it should also be important for any other observation where fluorescence microscopy is involved, for example, fluorescence microscopy of antigen-antibody reactions, the location of antigen then being observable directly within the cell.

A much easier, but less convenient, arrangement can be made by drawing an annular ring with a fluorescent material on a slide. When this is properly centred, a similar phase-fluorescence image is obtained.

Such arrangement does not necessarily require a phase objective. With an ordinary objective, one can obtain a bright field and fluorescent image.

Details of the work will be published elsewhere.

I acknowledge with thanks the help received from Dr. W. H. Steel and Mr. D. G. Puttock of the Commonwealth Scientific and Industrial Research Organization, Sydney.

Microbiology Laboratories,

Faculty of Agriculture,

University of Sydney.

${ }^{1}$ Tchan, Y. T., Proc. Linn. Soc. N.S.W., 77, 265 (1953).

\section{Direct Chelatometric Method for the Estimation of Calcium or Magnesium in the Presence of Phosphate}

ACCORDING to the classical procedures, determination of calcium in the presence of phosphate is carried out by precipitation as the oxalate in acetic acid medium in presence of ammonium citrate', and subsequent ignition of the separated precipitate. Magnesium is determined gravimetrically by precipitating it as the phosphate and this precipitate is then ignited to its pyrophosphate for weighing.

These procedures are lengthy and time consuming. Chelatometric procedures recently introduced by Schwarzenbach $^{2}$, Pribil $^{3}$ and others provide extremely rapid methods for the estimation of calcium or magnesium when present alone ${ }^{4}$. In the presence of phosphates, however, their estimation is attended with difficulty. Methods have recently been described in which the calcium is separated from the phosphate by ion-exchange methods ${ }^{5}$ and the calcium thus freed from the phosphate is determined by a complexometric (chelatometric) method. Several other methods have been described which are tedious, indirect ${ }^{8}$ or more involved. We have attempted to develop a method which is simple, direct, accurate and very rapid.
A solution of zinc complexonate is prepared by mixing equivalent quantities of a solution of zine and disodium salt of 1-2 diamino cyclohexanetetra-acetic acid (chenta acid). This is mixed with an aliquot of the solution of calcium or magnesium phosphate and the $p H$ brought to $3-4$. The mixture is shaken well, and then its $p \mathrm{H}$ is adjusted to 8-10 by addition of ammonium chloride ammonium hydroxide buffer solution, a few drops of eriochrome black $T$ indicator are added and the solution titrated against a standard solution of the disodium salt of chenta acid.

In the case of a calcium solution, the titration should be carried out almost immediately at ordinary temperatures. Towards the end, however, the titration becomes slow, and the titration is completed after heating the solution to about $60-70^{\circ} \mathrm{C}$. and gradual addition of the chenta.

In the case of a magnesium solution, however, the solution has to be kept hot throughout the titration, and it takes a little longer to finish the titration.

In each case the determination can be completed in a few minutes, as compared to several hours required by the usual gravimetric determination, and here the titre gives a direct measure of the quantity of calcium or magnesium.

In Tables 1 and 2 are some typical results. The determination gives the quantity of calcium $(\mathrm{CaO})$ or magnesium ( $\mathrm{MgO}$ ) present in $500 \mathrm{ml}$. of the given solution containing varying amounts of phosphates; $25 \mathrm{ml}$. of the solution was used for each titration.

Table 1. Determination of Calcium in Presence of Phospeate

\begin{tabular}{|c|c|c|c|}
\hline $\begin{array}{l}\text { Molar ratio } \\
\mathrm{P}_{2} \mathrm{O}_{5} / 3 \mathrm{CaO}\end{array}$ & \multicolumn{2}{|c|}{${ }_{\text {Present }}^{\mathrm{CaO}(\mathrm{gm} .)}$ Found } & $\underset{\text { (per cent) }}{\text { Error }}$ \\
\hline $\begin{array}{l}0 \cdot 9 \\
2 \cdot 26 \\
2 \cdot 4 \\
5 \cdot 7\end{array}$ & $\begin{array}{l}0 \cdot 6804 \\
0 \cdot 2733 \\
0 \cdot 2330 \\
0 \cdot 1022\end{array}$ & $\begin{array}{l}0 \cdot 6846 \\
0 \cdot 2731 \\
0 \cdot 2343 \\
0 \cdot 1023\end{array}$ & $\begin{array}{l}+0.6 \\
+0.1 \\
+0.2 \\
+0.1\end{array}$ \\
\hline
\end{tabular}

Table 2. Determination of Magnesiom in Presence of Phosphate

\begin{tabular}{|c|c|c|c|}
\hline \multirow{2}{*}{$\begin{array}{c}\begin{array}{c}\text { Molar ratio } \\
\mathrm{P}_{2} \mathrm{O}_{8} / 3 \mathrm{MgO}\end{array} \\
0 \cdot 90 \\
1.53 \\
4.2\end{array}$} & \multicolumn{2}{|c|}{$\begin{array}{c}\mathrm{MgO}(\mathrm{gm} .) \\
\text { Present }\end{array}$} & \multirow{2}{*}{$\begin{array}{c}\begin{array}{c}\text { Error } \\
\text { (per cent) }\end{array} \\
-0 \cdot 2 \\
+0 \cdot 3 \\
\text { Nil }\end{array}$} \\
\hline & $\begin{array}{l}0 \cdot 1770 \\
0.2760 \\
0.0984\end{array}$ & $\begin{array}{l}0 \cdot 1767 \\
0 \cdot 2768 \\
0 \cdot 0984\end{array}$ & \\
\hline
\end{tabular}

The method is being extended to the analysis of phosphatic fertilizers, and conditions are being worked out for avoiding the interference due to other constituents normally present in these materials. Full details, with possible mechanisms of the reactions, will be published elsewhere. Our thanks are due to the J. R. Geigy Co., of Basle, for the gift of a quantity of chenta acid, which has made this investigation possible.

M. R. VERMA

V. M. BHUCHAR

K. J. Therattil

National Physical Laboratory of India,

New Delhi.

Feb. 14.

1 Lunge, G., and Keane, C. A., "Technical Methods of Chemical Analysis", 3, 519 and 530 (Gurney and Jackson, London, 1931). ${ }^{2}$ Schwarzenbach, G., Analyst, 80, 713 (1955).

"Pribil, R., "Complexometrie" (Chemapol, Prague, 1954).

`Verma, M. R., and Therattil, K. J.. J. Sci. Indust. Res., 15A, Supp. 1 (1956). Geigy Industrial Chemicals, New York, "Sequestrene and Chel". 'Tech. Bull. (1952).

5 Bruniskolz, G., Genton, M., and Plattner, E., Helv. Chim. Acta, 36, $782(1953)$. Schilz, W. E., and Krynaw, G. N., Anal. Chem.,
28, 1759 (1956).

${ }^{6}$ Pribil, R., and Jelinkova, V. Chem. Listy, 46, 403 (1952). 